\section{Prevalence of precancerous skin lesions and non-melanoma skin cancer in Japanese-Brazilians in Bauru, São Paulo State, Brazil}

\author{
Prevalência de lesões pré-neoplásicas e tumores \\ cutâneos não melanomas em nipo-brasileiros \\ residentes na cidade de Bauru, São Paulo, Brasil
}

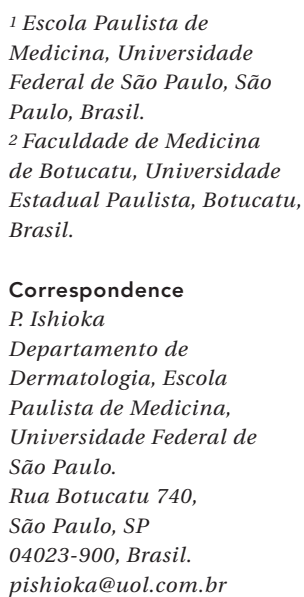

\begin{abstract}
Precancerous lesions and skin cancer are infrequent in Asians, and have received little documentation in the literature. Brazil has the world's largest contingent of Japanese immigrants and their descendants, and 70\% live in the State of São Paulo. The prevalence of such skin lesions in Japanese-Brazilians is unknown. This study aimed to assess the prevalence of actinic keratoses and non-melanoma skin cancer in first and second-generation Japanese-Brazilians over 30 years of age, without miscegenation, living in the city of Bauru, São Paulo State, in 2006. Of the 567 Japanese-Brazilians that underwent dermatological examination, actinic keratosis was diagnosed in 76, with a mean age of 68.9 years, and a single case of basal cell carcinoma was detected in a 39-year-old female patient. In Japan, prevalence of actinic keratosis varies from $0.76 \%$ to $5 \%$, and the incidence of non-melanoma skin cancer is 1.2 to 5.4/100 thousand. Japanese-Brazilians from Bauru showed a $13.4 \%$ prevalence of actinic keratoses and earlier age at onset. Proximity to the Equator and a history of farming contribute to these higher rates. Presence of solar melanosis was associated with a 1.9-fold risk of developing actinic keratosis.
\end{abstract}

Skin Neoplasms; Skin Manifestations; Solar Radiation

\author{
Priscila Ishioka 1 \\ Sílvio Alencar Marques 2 \\ Amélia Toyomi Hirai 1 \\ Mariangela E. A. Marques 2 \\ Sérgio Henrique Hirata ${ }^{1}$ \\ Sérgio Yamada 1
}

\section{Introduction}

Skin cancers are the most common malignant tumors in Brazil and the United States, where they account for $20 \%-30 \%$ of neoplasms in Caucasians, $2 \%-4 \%$ in Asians, and $1 \%-2 \%$ in Blacks 1 . The worldwide incidence of non-melanoma skin cancer (basal cell carcinoma, squamous cell carcinoma, and Bowen's disease) has increased by $4 \%-8 \%$ per year since 19602 . Three million cases of non-melanoma skin cancer and 132 thousand melanomas are diagnosed worldwide each year 3. In Brazil, the number of new cases of non-melanoma skin cancer in 2006 was estimated at 55,480 in men and 61,160 in women. These figures correspond to an estimated risk of 61 new cases per 100 thousand men and 65 per 100 thousand women 4 .

In Japan, since 1987, the Japanese Skin Cancer Society has studied the epidemiology of malignant skin tumors. A recent national survey by this society showed a higher prevalence of basal cell carcinoma in the Japanese population and a non-melanoma skin cancer incidence of 1.2 to 5.4 per 100 thousand inhabitants 5,6,7 .

Since Caucasians have a lower concentration of melanin in the skin, they are more susceptible to skin damage from sun exposure. Melanin promotes the absorption of UVA and UVB rays, reducing the unwanted effects of solar radiation in this spectrum of the wavelength, responsible 
for the genesis of precancerous and malignant skin lesions.

Actinic keratosis is a precancerous lesion with a $0.1 \%-20 \%$ conversion rate to squamous cell carcinoma 8,9,10. It occurs mainly in Caucasians that are chronically exposed to solar radiation and identifies groups at risk of developing skin cancer. Non-melanoma skin cancer is 70 times more frequent in individuals with light skin 1 . Facilitating factors in the development of actinic keratoses and non-melanoma skin cancer are genetically determined. Other risk factors are immunosuppression and certain genetic disorders like xeroderma pigmentosum.

Highly prevalent benign skin lesions such as solar melanosis, leukoderma punctatum, and solar elastosis also express actinic damage, and just as malignant skin lesions, they are more frequent in Caucasians. Chronic sun exposure in individuals with more skin pigment, as in Blacks and Asians, can also cause solar melanosis, leukoderma punctatum, actinic keratosis, and occasionally skin cancer.

Epidemiological studies of actinic skin alterations in Asian and African descendants are poorly documented. Inconsistent recording of positive cases, together with low prevalence, hinder real estimates of their incidence.

Non-Caucasians represent $30 \%$ of the United States population, and the Asian-descendant population in the Americas is estimated to increase by $36 \%$ in the coming years 11 . In Brazil, of the total population of 169 million, 762 thousand are Asian-descendant and another 735 thousand are indigenous (Instituto Brasileiro de Geografia e Estatística. Censo Demográfico de 2000. http:// www.ibge.gov.br). Brazil has the world's largest contingent of Japanese immigrants (and their descendants), and $70 \%$ of them live in the State of São Paulo 12. The prevalence of actinic keratosis and non-melanoma skin cancer in Japanese-Brazilians is unknown.

The Japanese migratory movement to Brazil lasted from 1908 to the early 1960s, and the city of Bauru, São Paulo State, is home to an important part of this community. Bauru is located at latitude $22^{\circ}$ South, with an average temperature of $26.3^{\circ} \mathrm{C}$ in January and $19^{\circ} \mathrm{C}$ in July. The urban population totals 310,442 , with another 5,622 living in the countryside (Instituto Brasileiro de Geografia e Estatística. Censo Demográfico de 2000. http://www.ibge.gov.br). The city has 3 thousand Japanese-Brazilians; the majority live inside the city limits, but many have farmed in the past for varying periods of time 12 .

The aim of this study was to assess the prevalence of actinic keratoses and non-melanoma skin cancer in Japanese-Brazilians over 30 years of age, including first-generation (born in Japan) and second-generation (children of the former), without miscegenation, living in the city of Bauru in the year 2006 .

\section{Method}

This cross-sectional epidemiological study used data from the third phase of the study conducted by the Japanese-Brazilian Diabetes Study Group in the same community.

The population was identified through a 1997 demographic survey of the Japanese-Brazilian community in the city of Bauru. At the time, 1,751 first and second-generation individuals older than 30 years were located. Of these, 1,330 participated in the second phase of the study conducted by the Japanese-Brazilian Diabetes Study Group in the year 2000. In 2006, the 1,751 individuals were invited again through telephone calls, posters, and TV and radio ads, and 567 participants responded affirmatively to the invitation. In the third phase, in addition to the clinical examination, lab tests, nutritional assessment, and session with a physical therapist, a dermatological examination was included, which was announced to participants in advance, along with the invitation.

In the year 2006, these Japanese-Brazilians underwent a dermatological examination by two specialists, and suspicious lesions were submitted to biopsy and anatomopathological examination. Patients were examined in the outpatient clinic of the Sacred Heart University in Bauru. All the individuals voluntarily answered the questionnaire prepared by the examiners, which included the following information: identification, age, gender, generation, time living in Brazil, schooling, residential area (urban versus rural), time living in the rural area, occupation, leisure time activities, and personal or family history of skin cancer. The workup consisted of a thorough dermatological clinical examination, dermatoscopic examination of any suspicious pigmented lesions, photographic recording of skin alterations, and biopsy of premalignant and malignant lesions by the examiners themselves and anatomopathological analysis of the excised material at the Pathology Department, Botucatu School of Medicine, Universidade Estadual Paulista.

\section{Statistical analysis}

The data were expressed as the mean \pm standard deviation for the quantitative variables and as number and percentage for the qualitative variables. Point prevalence of actinic keratosis was 
calculated using as the denominator the total number of individuals in the sample; the respective $95 \%$ confidence intervals $(95 \% \mathrm{CI})$ were also calculated.

In the univariate analysis, the existence of associations with actinic keratosis was verified using the Student's t test for independent samples, chi-square, and odds ratio (OR). Multivariate analysis used an unconditional logistic regression model. The variables comprising the logistic model were those showing $\mathrm{p}<0.20$ in the univariate analysis; those that failed to present statistical significance $(p<0.05)$ were eliminated in stepwise fashion.

Data analysis used SPSS 12.0 for Windows (SPSS Inc., Chicago, USA).

\section{Ethical aspects}

The study was approved by the Institutional Review Board of the Federal University in São Paulo (CEP0862/05), with free informed consent obtained in writing from all the participants. The examiners were responsible for the clinical diagnosis of the various skin diseases, medical orientation, and adequate referral with an appropriate letter addressed to the health plan physicians or primary care clinic in the city of Bauru for those whose required dermatological follow-up.

\section{Findings}

The study sample included 567 first or secondgeneration Japanese-Brazilians over 30 years of age, without miscegenation, living in Bauru in the year 2006. Females comprised the majority (56.8\%), and participants' mean age was $61.2 \pm$ 11.4 years. Approximately $16 \%$ of these JapaneseBrazilians were first-generation, having lived in Brazil for more than 50 years. The vast majority lived inside the city limits (92.8\%), but $56.4 \%$ had farmed or lived in the countryside for more than 10 years. Only $11.6 \%$ had less than a complete primary education, and $27.7 \%$ had university degrees.

Actinic keratosis was diagnosed in 76 patients [prevalence rate of 13.4\% (95\%CI: 10.7-16.5)], with mean age at onset of $68.9 \pm 9.9$ years. As shown in Table 1, there was a higher prevalence of actinic keratosis among males, first-generation, those who had lived in the countryside for more than 20 years, and those with less schooling.

Table 2 shows the final model obtained from the multivariate analysis for the presence of actinic keratosis, showing that age, gender, and time in the rural area were independently associated with actinic keratosis.

Prevalence of solar melanosis in JapaneseBrazilians living in Bauru was 73\% (95\%CI:

Distribution of demographic data, odds ratios (OR), and 95\% confidence intervals (95\% Cl), according to presence or absence of actinic keratosis in Japanese-Brazilians in Bauru, São Paulo State, Brazil, 2006.

\begin{tabular}{|c|c|c|c|c|c|}
\hline & \multicolumn{2}{|c|}{ Actinic keratosis } & \multirow[t]{2}{*}{ OR } & \multirow[t]{2}{*}{$95 \% \mathrm{Cl}$} & \multirow[t]{2}{*}{$p$ value } \\
\hline & $\begin{array}{l}\text { Present } \\
(n=76)\end{array}$ & $\begin{array}{c}\text { Absent } \\
(n=491)\end{array}$ & & & \\
\hline Age (years) & $68.9 \pm 9.9$ & $60.0 \pm 11.1$ & 1.084 & $1.056-1.113$ & $<0.001$ \\
\hline Gender & & & & & 0.011 \\
\hline Male & $43(56.6 \%)$ & $202(41.1 \%)$ & 1.866 & $1.144-3.040$ & \\
\hline Female & $33(43.4 \%)$ & 289 (58.9\%) & 1.000 & - & \\
\hline Generation & & & & & $<0.001$ \\
\hline 1st-generation & $24(31.6 \%)$ & $64(13.0 \%)$ & 3.079 & $1.776-5.339$ & \\
\hline 2nd-generation & $52(68.4 \%)$ & $427(87.0 \%)$ & 1.000 & - & \\
\hline Time living in rural area (years) & & & & & $<0.001$ \\
\hline$<5$ & $14(18.4 \%)$ & $193(39.3 \%)$ & 1.000 & - & \\
\hline $5-10$ & $2(2.6 \%)$ & $38(7.7 \%)$ & 0.726 & $0.158-3.324$ & \\
\hline $11-20$ & $11(14.5 \%)$ & $107(21.8 \%)$ & 1.417 & $0.622-3.232$ & \\
\hline$>20$ & 49 (64.5\%) & $153(31.2 \%)$ & 4.415 & $2.350-8.296$ & \\
\hline Schooling & & & & & 0.005 \\
\hline$<$ Complete primary & $12(15.8 \%)$ & $54(11.0 \%)$ & 2.685 & $1.137-6.339$ & \\
\hline Complete primary & $39(51.3 \%)$ & $168(34.2 \%)$ & 2.805 & $1.415-5.560$ & \\
\hline Complete secondary & $13(17.1 \%)$ & $124(25.3 \%)$ & 1.267 & $0.558-2.877$ & \\
\hline University & $12(15.8 \%)$ & $145(29.5 \%)$ & 1.000 & - & \\
\hline
\end{tabular}


Table 2

Odds ratios (OR) and $95 \%$ confidence intervals $(95 \% \mathrm{Cl})$ for presence of actinic keratosis in Japanese-Brazilians in Bauru, São Paulo State, Brazil, adjusted for other variables.

\begin{tabular}{lccc}
\hline & OR & $95 \% \mathrm{Cl}$ & p value \\
\hline $\begin{array}{l}\text { Age (years) } \\
\text { Gender }\end{array}$ & 1.068 & $1.039-1.098$ & $<0.001$ \\
$\quad$ Male vs. female & & & 0.013 \\
Time living in rural area (years) & 1.932 & $1.152-3.244$ & 0.008 \\
$5-10$ vs. $<5$ & & & \\
$11-20$ vs. $<5$ & 0.654 & $0.137-3.114$ & \\
$>20$ vs. $<5$ & 1.136 & $0487-2.647$ & \\
\hline
\end{tabular}

69.2-76.3) and leukoderma punctatum was $24 \%$ (95\%CI: 20.2-27.4). Mean age at onset was $63.2 \pm$ 10.7 and $64.3 \pm 9.9$ years, respectively.

In $82.9 \%$ of the Japanese-Brazilians that presented actinic keratosis, solar melanosis was also diagnosed in sun-exposed areas. Individuals with solar melanosis had a 1.9-fold risk of developing actinic keratosis. The association between actinic keratosis and leukoderma punctatum was not statistically significant (Table 3).

No cases of squamous cell carcinoma or Bowen's disease were diagnosed in this study. A single case of solid basal cell carcinoma was detected, with pigmented scleroderma-like areas on the face. The patient was a 39-year-old second-generation female living in the urban area of Bauru, with no personal or family history of skin cancer and no history of extensive sun exposure.

\section{Discussion}

Racial differences in pigmentation do not depend on the number of melanocytes in the skin, but on their functional capacity. The cytoplasm of the melanocytes contains specialized organelles called melanosomes, the site for synthesis and deposition of melanin, a brown pigment that gives the skin its color 13. Dark-skinned individuals show greater activity in the melanocytes, with more production and dispersion of melanin in the melanosomes. Meanwhile, Caucasians show reduced production of this pigment, and the melanosomes are smaller and are found grouped in the melanocytes 14 . This cell structure conformation provides high protection against ultraviolet rays in ethnic groups with darker skin. The epidermis of Black individuals shows $7.4 \%$ UVB and $17.5 \%$ UVA ray transmission, as compared to $24 \%$ and $55 \%$ in Caucasians, respectively. The minimum dose of solar radiation that produces skin erythema in Blacks is 6-33 higher than that needed to produce the same effect in Whites 1 .

Solar radiation causes an increase in the size of the melanocytes and melanosomes, stimulates tyrosinase activity (with increased melanin production), and acts as the principal risk factor for the development of precancerous and malignant skin lesions. UVA (wavelength 320-400nm) and UVB rays $(280-320 \mathrm{~nm})$ are initiators and promoters of carcinogenesis, promote mutation of the p53 tumor suppressor gene, and also exert immunosuppressive action 9,15.

Proximity to the Equator, greater sun exposure, and farming are important factors in the genesis of precancerous and malignant lesions, which are more frequent in Caucasians since they have less skin pigment. Individual and genetic factors such as p53 mutation also act in

Distribution of solar melanosis and leukoderma punctatum according to presence or absence of actinic keratosis in JapaneseBrazilians in Bauru, São Paulo State, Brazil, 2006.

\begin{tabular}{|c|c|c|c|c|c|}
\hline & \multicolumn{2}{|c|}{ Actinic keratosis } & \multirow[t]{2}{*}{ OR } & \multirow[t]{2}{*}{$95 \% \mathrm{Cl}$} & \multirow[t]{2}{*}{$p$ value } \\
\hline & $\begin{array}{l}\text { Present } \\
(n=76)\end{array}$ & $\begin{array}{c}\text { Absent } \\
(n=491)\end{array}$ & & & \\
\hline Solar melanosis & & & & & 0.037 \\
\hline Yes & $63(82.9 \%)$ & 351 (71.5\%) & 1.933 & $1.031-3.623$ & \\
\hline No & $13(17.1 \%)$ & $140(28.5 \%)$ & 1.000 & - & \\
\hline Leukoderma & & & & & 0.241 \\
\hline Yes & $22(28.9 \%)$ & 112 (22.8\%) & 1.379 & $0.804-2.263$ & \\
\hline No & $54(71.1 \%)$ & $379(77.2 \%)$ & 1.000 & - & \\
\hline
\end{tabular}


the etiopathogenesis. As identified in patients with xeroderma pigmentosum, a mutation was observed in codons $247-248$ of the p53 gene in sun-exposed skin in $12 \%$ of Japanese that presented benign or malignant skin tumors and in 63.6\% of Caucasian Australians 16. This mutation was more frequent in individuals over 70 years of age with a positive personal history of premalignant or malignant skin lesions, and did not occur in unexposed areas. The p53 mutation can be considered a molecular marker of UV radiation and is genetically influenced, and there is speculation on its use as a predictive factor for skin cancer.

As in Caucasians, an increase was observed in the incidence of premalignant and malignant skin lesions in Asians and Blacks. Destruction of the ozone layer, which absorbs part of the sunrays, is a contributing factor: a decrease of only $10 \%$ in the ozone layer results in an increase of 300 thousand cases of non-melanoma skin cancer 3 .

In Southeast Japan, where the intensity of UV rays is twice that of the Northeast region of the country, incidence of basal cell carcinoma and squamous cell carcinoma is six times higher 17,18. On the island of Kauai, in Hawaii, the incidence of non-melanoma skin cancer is 45 times higher in Japanese immigrants as compared to Japanese (in Japan) 7. The predominance of farming in this immigrant community in Hawaii and proximity to the Equator (latitude $22^{\circ} \mathrm{N}$ ) contribute to this high incidence 19,20.

Our study showed a single case of pigmented basal cell carcinoma located on a sun-exposed area in a relatively young female patient. Pigmented histology is the most frequently diagnosed type in Asians and Blacks, and $75 \%$ of cases are located on the head and neck 21,22 . The present study did not find any cases of other nonmelanoma skin cancer like squamous cell carcinoma or Bowen's disease. The small case sample may explain this finding.

In Japan, prevalence of actinic keratosis is $0.76 \%-5 \% 19,23,24$. Actinic keratosis is 3.5 times more frequent in the Southeast of the country, which receives a higher dose of UV rays, and five times more frequent in Japanese fishermen as compared to farmers 25 . It occurs primarily in males and on sun-exposed areas. The JapaneseBrazilians from Bauru showed a $13.4 \%$ prevalence of actinic keratoses and earlier age at onset. Time living in the countryside and the predominance of farming in this Japanese-Brazilian community contributed to this high prevalence.

Table 4 shows the prevalence of actinic keratosis in different studies of Japanese living in Okinawa (Ie Island) 19 and Kasai (central Japan) 24 and in Japanese-Brazilians in Bauru. The data cannot be compared, since the population samples are different, with distinct inclusion criteria. However, the table highlights the greater frequency of actinic keratoses in regions closer to the Equator.

In our study, Japanese-Brazilians with solar melanosis showed a 1.9-fold risk of developing actinic keratosis. History of sunburn with blistering in childhood and presence of more than six seborrheic keratoses in exposed areas were also associated with greater risk of developing actinic keratosis among Japanese in Kasai 24.

Precancerous and malignant skin alterations are infrequent in Asians. The mortality rate for non-melanoma skin cancer is low in the Japanese population, but a $3.8 \%$ annual increase was observed in this population 26,27 .

As compared to Japanese, Japanese-Brazilians present a higher risk of developing these skin

Prevalence of actinic keratoses in Japanese-Brazilians in Bauru, São Paulo, Brazil, and in Japanese in Kasai 19,24 and le Island, Japan 23,25.

\begin{tabular}{|c|c|c|c|c|c|c|c|c|c|}
\hline City/Country & Latitude & Inhabitants * & Study year & $\begin{array}{c}\text { Age } \\
\text { (years) }\end{array}$ & Study N & $\%$ ** & $\begin{array}{c}\text { Actinic } \\
\text { keratosis }\end{array}$ & Mean age & $\begin{array}{c}\text { Basal cell } \\
\text { carcinoma (n) }\end{array}$ \\
\hline Bauru/Brazil & $22^{\circ} \mathrm{S}$ & 3,000 & 2006 & $>30$ & $\begin{array}{c}567 \text { (male: } 43 \% \\
\text { female: } 57 \% \text { ) }\end{array}$ & 32 & $76(13.40 \%)$ & 69 & 1 \\
\hline le Island/Japan & $25^{\circ} 10^{\prime} \mathrm{N}$ & 5,562 & 1993-1996 & $\geq 40$ & $\begin{array}{c}\text { 1,690 (male: } 42 \%, \\
\text { female: } 58 \% \text { ) }\end{array}$ & 65 & $86(5.00 \%)$ & 71 & 9 \\
\hline Kasai/Japan & $34^{\circ} 56^{\prime} \mathrm{N}$ & 52,837 & 1992 & $>20$ & $\begin{array}{c}\text { 4,736 (male: } 34 \%, \\
\text { feminine: } 66 \% \text { ) }\end{array}$ & 12 & $36(0.76 \%)$ & 70 & 2 \\
\hline
\end{tabular}

* Estimated number of Japanese-Brazilians and Japanese in the respective cities;

** Percentage of inhabitants evaluated according to age criterion. 
alterations because they live in a tropical country with intense exposure to ultraviolet rays, and with a predominantly agricultural economy in some regions ${ }^{28}$. The Japanese-Brazilians of Bauru live in a city in the interior of São Paulo State, located at latitude $22^{\circ}$ South, with high temperatures and farming as the predominant economic activity. These important risk factors help explain the high prevalence of actinic keratosis in this community.

Asians require prolonged exposure to sunrays and high doses of ultraviolet radiation to induce actinic damage. Rural activities with greater sun exposure, proximity to the Equator, and extended time of residence in tropical countries may contribute to the increase in the incidence of these lesions in Japanese immigrants in Hawaii 7,20, and the same occurs with Japanese-Brazilians in Bauru.

This study's goal was to alert health professionals to the high prevalence of actinic keratosis in Japanese-Brazilians. The study is unique in Brazil and highlights the importance of early diagnosis of premalignant signs and non-melanoma skin cancer in the country's Japanese community.

\section{Resumo}

Manifestações cutâneas pré-neoplásicas e neoplásicas em asiáticos são infreqüentes e pouco documentadas. O Brasil possui o maior contingente de imigrantes japoneses e 70\% deles residem no Estado de São Paulo. A prevalência dessas lesões em nipo-brasileiros é desconhecida. O presente estudo tem como objetivo avaliar a prevalência de queratoses actínicas e tumores cutâneos não melanomas em nipo-brasileiros acima de trinta anos de la geração ou 2a geração, sem miscigenação, residentes na cidade de Bauru, no ano de 2006. Dos 567 nipo-brasileiros submetidos a exame dermatológico, diagnosticou-se queratose actínica em 76 pacientes, com média de idade de 68,9 anos, e único carcinoma basocelular em paciente do sexo feminino de 39 anos. No Japão, a prevalência de queratose actínica é de 0,76\% a 5\% e a incidência de tumores cutâneos não melanomas é de 1,2 a 5,4/100 mil. Os nipo-brasileiros de Bauru apresentaram prevalência de 13,4\% de queratoses actínicas e idade mais precoce de aparecimento. Proximidade com o Equador e atividades rurais contribuem para esses achados. A presença de melanose solar demonstrou risco 1,9 vez maior de desenvolver queratose actínica.

Neoplasias Cutâneas; Manifestações Cutâneas; Radiação Solar

\section{Contributors}

A. T. Hirai conducted the fieldwork together with the Japanese-Brazilian Diabetes Study Group in Bauru and assisted with the project design and literature review. S. H. Hirata and S. Yamada participated in the final text. S. A. Marques collaborated in the study design, fieldwork, and dermatological examination of the participants and collaborated in the final version of the manuscript. P. Ishioka collaborated in the study design, fieldwork, and dermatological examination of the participants, organized the database, analyzed the results, and conducted the literature review. M. E. A. Marques was responsible for the anatomopathological examination of the skin biopsies and conducted the final reading of the manuscript.

\section{Acknowledgments}

The authors wish to thank the following for their collaboration in the project: F. M. Oguro, A. Sañudo, and the members of the Japanese-Brazilian Diabetes Study Group: A. Hirai, H. Harima, K. Osiro, M. Iunes (in memoriam), M. Kikuchi, S. R. G. Ferreira, S. G. A. Gimeno, L. J. Franco, L. Matsumura, R. S. Moisés, V. D’Almeida, M. A. Cardoso, N. Barros Jr., N. Tomita, K. Wakisaka, and R. Chaim. 


\section{References}

1. Gloster Jr. HM, Neal K. Skin cancer in skin of color. J Am Acad Dermatol 2006; 55:741-60.

2. Housman TS, Feldman SR, Williford PM, Fleischer AB, Goldman ND, Acostamadiedo JM, et al. Skin cancer is among the most costly of all cancers to treat for the medicare population. J Am Acad Dermatol 2003; 48:425-9.

3. World Health Organization. Skin cancers. http:// www.who.int/uv/faq/skincancer/en/indexl.html (accessed on 11/Aug/2007).

4. Instituto Nacional de Câncer. Estimativa 2006: incidência de câncer no Brasil. http://www.inca.gov. br/estimativa/2006/tbregioes (accessed on 11/ Aug/2007).

5. Ishihara K, Saida T, Otsuka F, Yamazaki N; Prognosis and Statistical Investigation Committee of the Japanese Skin Cancer Society. Statistical profiles of malignant melanoma and other skin cancers in Japan: 2007 update. Int J Clin Oncol 2008; 13:33-41.

6. Qiu D, Tanaka S. International comparisons of cumulative risk of skin cancer, from Cancer Incidence in Five Continents Vol. VIII. Jpn J Clin Oncol 2006; 36:533-4.

7. Chuang TY, Reizner GT, Elpern DJ, Stone JL, Farmer ER. Nonmelanoma skin cancer in Japanese ethnic Hawaiians in Kauai, Hawaii: an incidence report. J Am Acad Dermatol 1995; 33:422-6.

8. Salasche SJ. Epidemiology of actinic keratoses and squamous cell carcinoma. J Am Acad Dermatol 2000; 42(1 Pt 2):4-7.

9. Callen JP, Bickers DR, Moy RL. Actinic keratoses. J Am Acad Dermatol 1997; 36:650-3.

10. Moy RL. Clinical presentation of actinic keratoses and squamous cell carcinoma. J Am Acad Dermatol 2000; 42(1 Pt 2):8-10.

11. Halder RM, Nootheti PK. Ethnic skin disorders overview. J Am Acad Dermatol 2003; 48(6 Suppl): S143-8.

12. Hirai A, Hirai AT, Brunieri DM, Harima HA, Osiro K, Wakisaka K, et al. Diabetes mellitus e doenças associadas em nipo-brasileiros. São Paulo: Departamento de Medicina Preventiva, Universidade Federal de São Paulo/Centro de Estudos Nipo-Brasileiros; 2004.

13 Sampaio SAP, Rivitti EA. Dermatologia. 3a Ed. São Paulo: Editora Artes Médicas; 2007.

14. Bolognia JL, Orlow SJ. Melanocyte biology. In: Bolognia JL, Jorizzo JL, Rapini RP, Horn TD, Mascaro JM, Mancini AJ, et al., editors. Dermatology. Madrid: Elsevier Limited; 2003. p. 935-46.

15. Ramos J, Villa J, Ruiz A, Armstrong R, Matta J. UV dose determines key characteristics of nonmelanoma skin cancer. Cancer Epidemiol Biomarkers Prev 2004; 13:2006-11.
16. Ouhtit A, Ueda M, Nakazawa H, Ichihashi M, Dumaz N, Sarasin A, et al. Quantitative detection of ultraviolet-specific p53 mutations in normal skin from Japanese patients. Cancer Epidemiol Biomarkers Prev 1997; 6:433-8.

17. Suzuki T, Ueda M, Ogata K, Horikoshi T, Munakata $\mathrm{N}$, Ichibashi M. Doses of solar ultraviolet radiation correlate with skin cancer rates in Japan. Kobe J Med Sci 1996; 42:375-88.

18. Ichibashi M, Naruse K, Harada S, Nagano T, Nakamura T, Suzuki T, et al. Trends in nonmelanoma skin cancer in Japan. Recent Results Cancer Res 1995; 139:263-73.

19. Naruse K, Ueda M, Nagano T, Suzuki T, Harada S, Imaizumi K, et al. Prevalence of actinic keratosis in Japan. J Dermatol Sci 1997; 15:183-7.

20. Leong GKP, Stone JL, Farmer ER, Scotto J, Reizner GT, Burnett TS, et al. Nonmelanoma skin cancer in Japanese residents of Kauai, Hawaii. J Am Acad Dermatol 1987; 17(2 Pt 1):233-8.

21. Kikuchi A, Shimizu H, Nishikawa T. Clinical histopathological of basal cell carcinoma in Japanese patients. Arch Dermatol 1996; 132:320-4.

22. Lee CS, Lim HW. Cutaneous diseases in Asians. Dermatol Clin 2003; 21:669-77.

23. Araki K, Nagano T, Ueda M, Washio F, Watanabe S, Yamaguchi N, et al. Incidence of skin cancers and precancerous lesions in Japanese: risk factors and prevention. J Epidemiol 1999; 9(6 Suppl):S14-21.

24. Suzuki T, Ueda M, Naruse K, Nagano T, Harada S, Imaizumi $\mathrm{K}$, et al. Incidence of actinic keratosis of Japanese in Kasai City, Hyogo. J Dermatol Sci 1997; 16:74-8.

25. Anzai S, Anan T, Kai Y, Goto M, Arakawa S, Shimizu F, et al. Skin cancer screening on a fishing island and in an island agricultural area of Japan. J Dermatol 2005; 32:875-82.

26. Takahashi K, Pan G, Feng Y, Ohtaki M, Watanabe S, Yamaguchi N. Regional correlation between estimated UVB levels and skin cancer mortality in Japan. J Epidemiol 1999; 9(6 Suppl):S123-8.

27. Ohtsuka H, Nagamatsu S. Changing trends in the number of deaths from nonmelanoma skin cancer in Japan, 1955-2000. Dermatology 2005; 210: 206-10.

28. Corrêa MP, Dubuisson P, Plana-Fattori A. An overview of the ultraviolet index and the skin cancer cases in Brazil. Photochem Photobiol 2003; 78 : 49-54.

Submitted on 25/Sep/2007

Final version resubmitted on 13/May/2008

Approved on 20/May/2008 